\title{
The protein-nanoparticle interaction (protein corona) and its importance on the therapeutic application of nanoparticles
}

\author{
Mahsa Sedighi ${ }^{1}{ }^{1,2}$, Mehdi Shakibaie ${ }^{(1,2 *}$
}

\begin{abstract}
Nanobiotechnology has provided promising novel diagnostic and therapeutic strategies which capable to create a broad spectrum of nano-based imaging agents and medicines for human administrations. Several studies have demonstrated that the surface of nanomaterials is immediately coated with suspended proteins after contact with plasma or other biological fluids to form protein corona-nanoparticle complexes. Cells react after exposure with these complexes. since, the biological fate and functions of nanomaterials are determined by physiological responses to protein -nanoparticle complexes in this article, we aimed to review some studies about the effects of the protein profiles and physicochemical characteristics of nanoparticles in the biological environment on the formation of protein corona and subsequent the biological responses upon exposure to nanoparticles. Also, some used methods for of protein corona analysis has been reviewed. It has been shown that the biological impacts of protein corona may be both constructive and/or destructive in the biomedical applications of nanomaterials. The protein corona-cell interactions can facilitate targeted delivery and cellular absorption of therapeutic nanomaterials and also, they mitigate the unfavorable cytotoxic effects of nanoparticles. On the other hand, these interactions may cause rapid clearance of nanoparticles from the body as well as the activation of undesirable inflammatory responses. Hence, the study of the formation mechanism and biological effects of protein corona plays an important role in the design of nanoparticles with specific physicochemical properties proportional with their intended biological activity.
\end{abstract}

Keywords: Biological identity, Nanobiotechnology, Protein corona, Targeted delivery

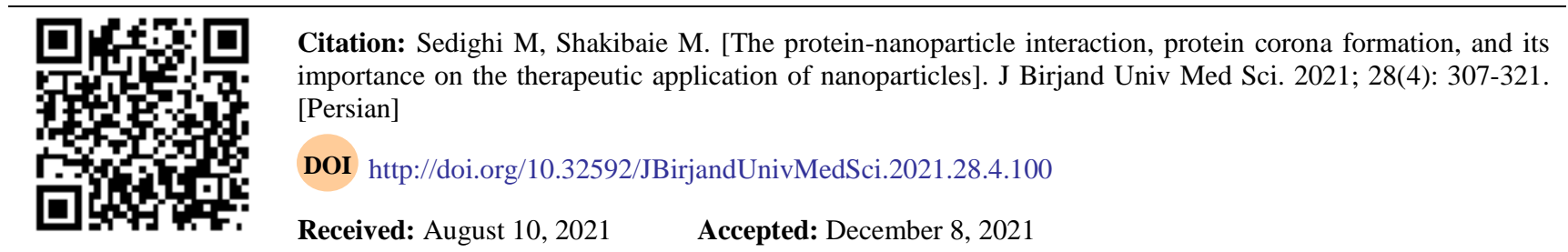

\footnotetext{
${ }^{1}$ Department of Nanomedicine, Faculty of Medicine, Birjand University of Medical Sciences, Birjand, Iran

${ }^{2}$ Cellular and Molecular Research Center, Birjand University of Medical Sciences, Birjand, Iran

* Corresponding author: Cellular and Molecular Research Center, Birjand University of Medical Sciences, Birjand, Iran Tel: +9856-32381924 


\title{
بر همكنش يروتئين -نانوذره (يروتئين كرونا) و اهميت آن در كاربرد درمانى نانوذرات
}

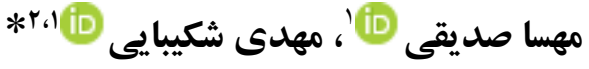

جكکبه

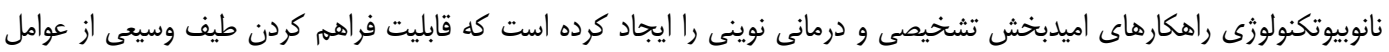

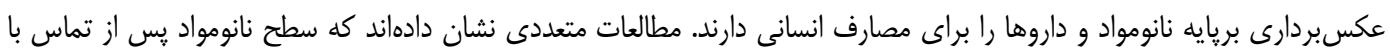

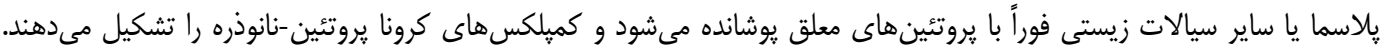

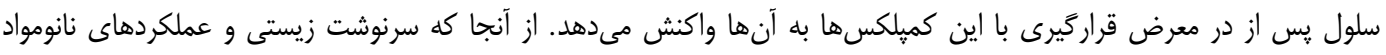

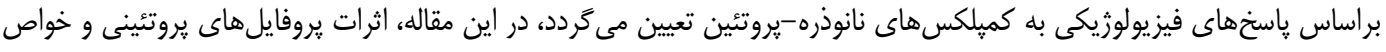

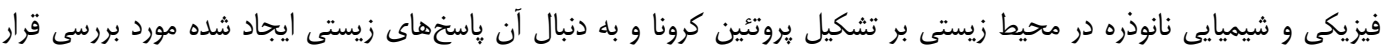

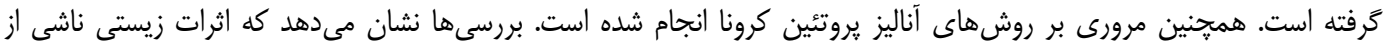

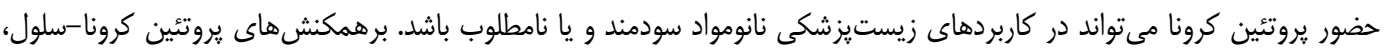

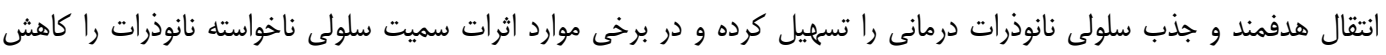

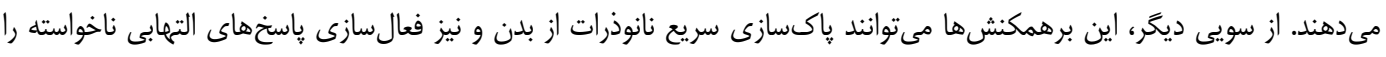

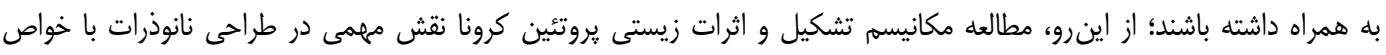
فيزيكى و شيميايى اختصاصى متناسب با فعاليت زيستى مورد نظر آنها دارد. وازههاى كليدى: مشخصه زيستى، نانوبيوتكنولوزى، يروتئين كرونا، انتقال هدفمند

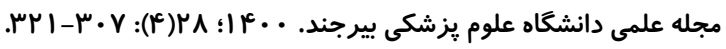
دريافت:

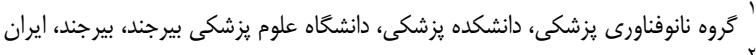

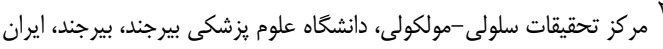


بر سطح نانوذره جذب مىشوند. اين يروتئينها سريعاً جدا شده و با

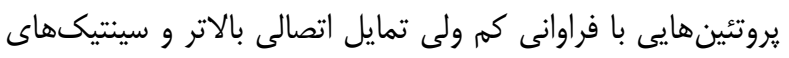

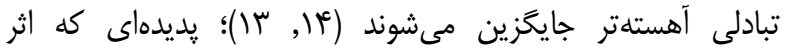

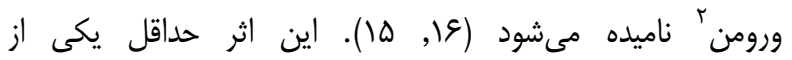

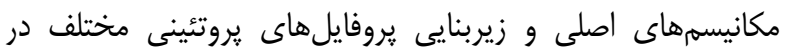

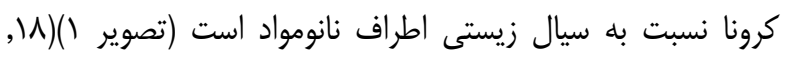

انواع گَوناگونى از نانو مواد تاكنون مورد بررسى قرار گرفتهاند كه داراى مشخصههاى فيزيكى و شيميايى متفاوتى هستند؛ به

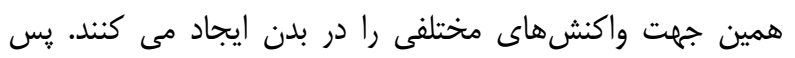

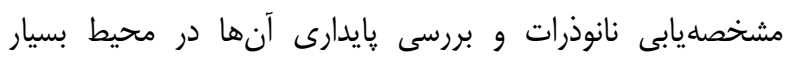

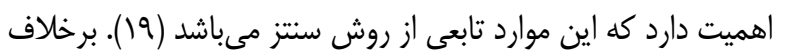

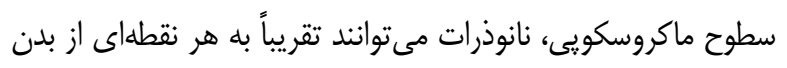

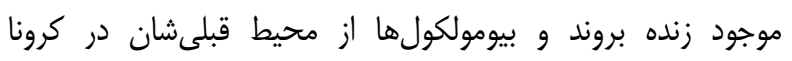

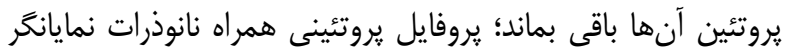

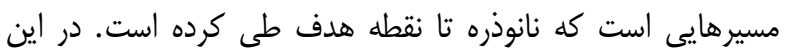

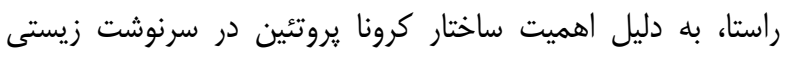
نانوذرات و دسترسى آنها به بافت مورد نظر، در اين مقاله، مرورى بر دير

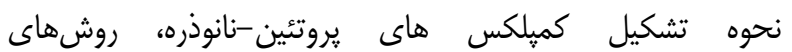
مشخصهيابى و اهميت درمانى آن خواهيم داشت.

\section{ا . كميلكسهاى نانوذره-كرونا يروتئين به عنوان مشخصdهاى زيستى نانوذرات}

يروتئين كرونايى كه بر روى سطح نانوذرات تشكيل مى شیود با بودراب قرارگيرى در معرض يكى محيط زيستى به دليل داشتن ماهيتى يويا،

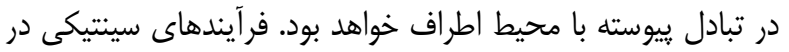
تبادل يروتئينها بين سطح نانوذره و يلاسما، بين سطح نانوذره و سطح سلول (شامل گيرندهاى اختصاصى)، و نيز نانوذرات و

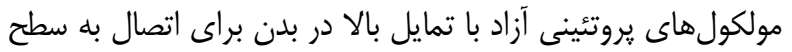

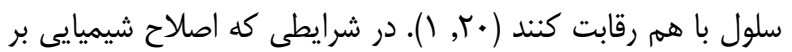

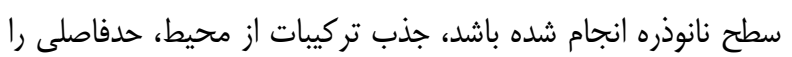

\footnotetext{
${ }^{2}$ Vroman effect
}

\section{مقله}

كنترل برهمكنش نانومواد با سيستمهاى زيستى جالش اساسى

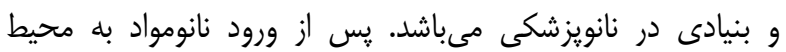

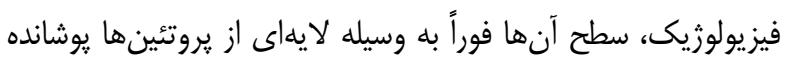

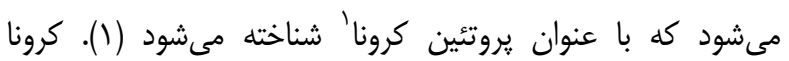

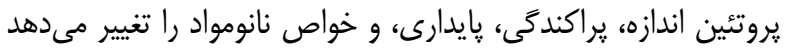
و باعث تغيير مشخصه زيستى آنها مىشود. اين تغيير، تعيين كننده

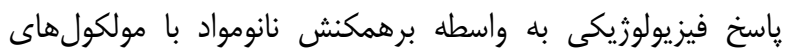

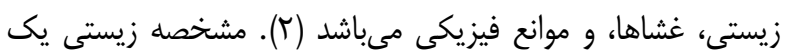

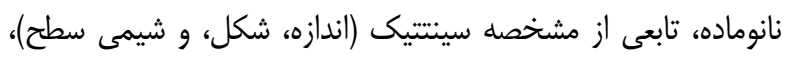

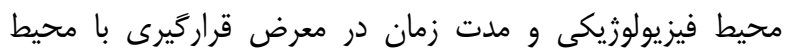

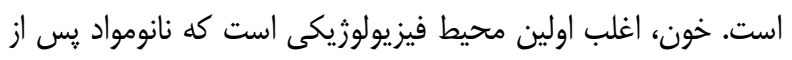

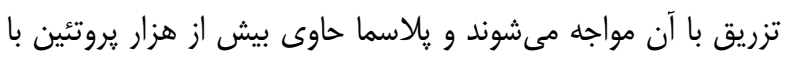

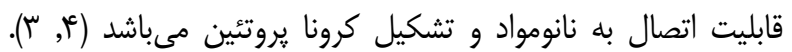
يروتئينها مىتوانند در شكل طبيعى يا دناتوره شده بسته به بار بـار بردين

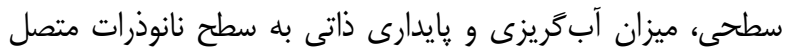
شوند. اين خواص نانوذرات است كه واكنشهاى خونى بودساماندهى يروتئين را تحت تأثير قرار داده و سبب انحرافاتى در فرآيندهاى استى زيستى يا منجر به بيمارىهايى در ارتباط با تاخوردگى نادرست

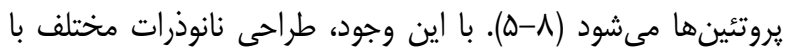
توجه به هدف و كاربرد مورد نظر مىبايست با دقّت انجام كردد تا از باز

$$
\text { واكنشهاى ناخواسته جلوكيرى شود. }
$$

ييشرفتهاى اخير در مطالعه كرونا يروتئين نشان مىدهد كهد مشخصههاى كرونا يروتئين و فراوانى نسبى آنها ماهيتى يويا دارند

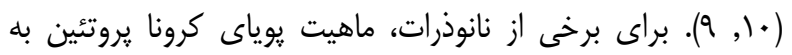

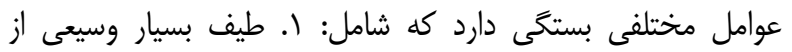
تمايلات اتصال و ثابتهاى تعادلى يروتئينها براى سطح نانوذره، كه ده طيف وسيعى از زمان بقاى يروتئينها را بر روى سطح به دنبال دارد

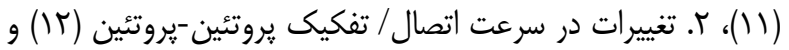

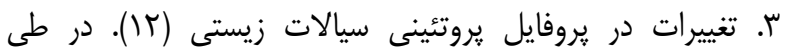

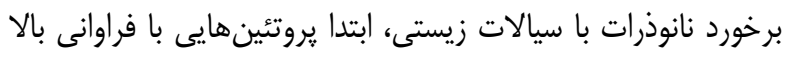

\footnotetext{
${ }^{1}$ Protein corona
} 


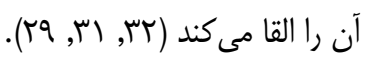
در بسيارى از موارد اين كرونا يروتئين است كه با سيستمهاى زيستى وارد برهمكنش مىشود و به موجب آن عنصر مهمى از

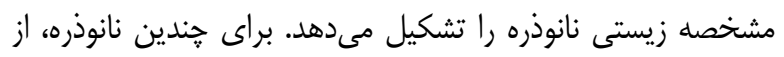

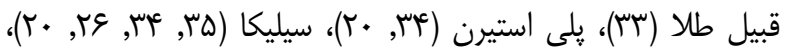

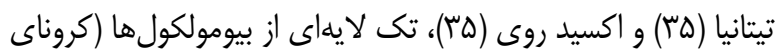
سخت) به سختى به سطح نانوذره متصل شده كه اين اتصال به طور

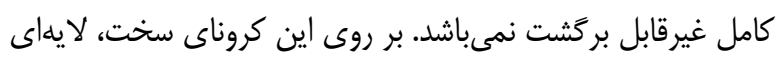

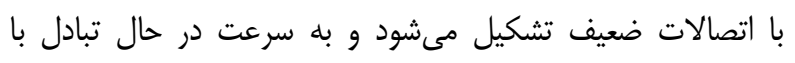

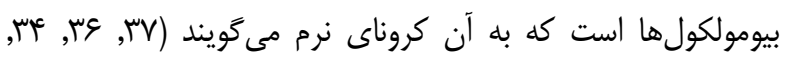

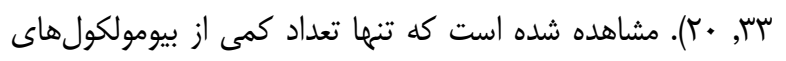
دردسترس در محيط زيستى، در كروناى سخت يافت مىشوند. از

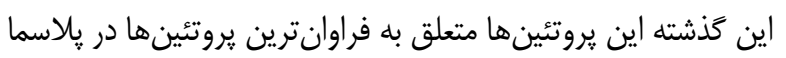

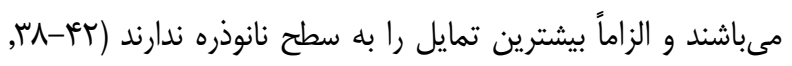

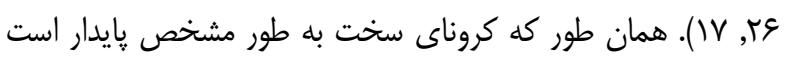

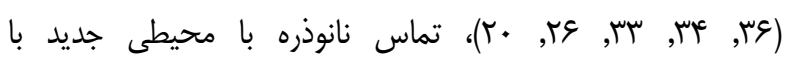
بيومولكولهاى متفاوت مىتواند منجر به جابجايى كروناى سخت

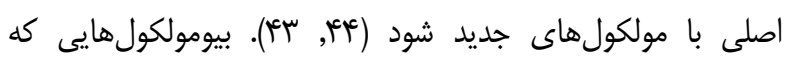
جايخزين نمىشوند به عنوان حافظه كرونايى محيط قبلى نانوذره

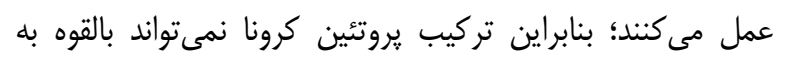

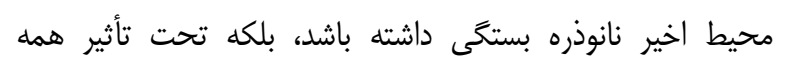
محيطهايى است كه از آن عبور كرده است. (تصوير r) (هأ, بَّ).
ايجاد مى كند كه عامل تعيين كننده كليدى در مسير هدفگيرى

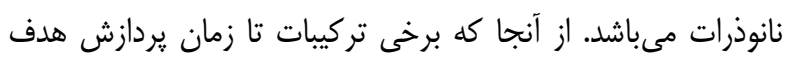

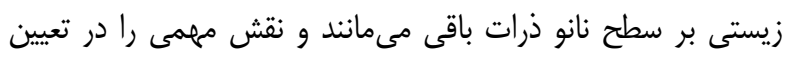

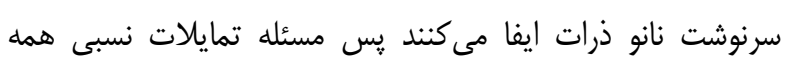
تركيبات سيسته بايد به درستى مورد مطالعه قرار كيرد (الآ). رفتار

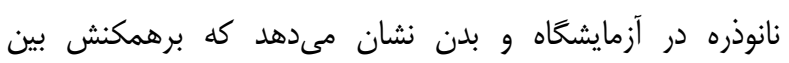

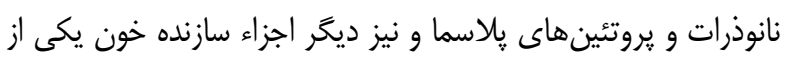
فاكتورهاى تعيين كننده اصلى در سرنوشت نانوذرات هستند. لايه بيه يروتئينى جذب شده نه تنها بر جذب سلولى و انتقال درونسلولى اثلى داثر

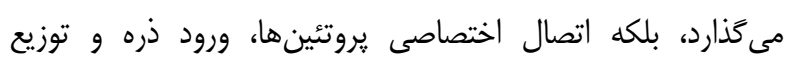

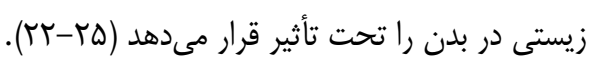

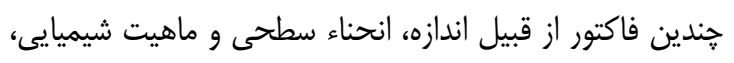

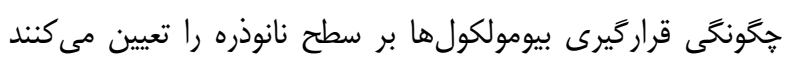
(qץ-צץ). با اين وجود، تعيين سرعتهاى اتصال، تمايلات تركيبات، و استوكيومترى اتصال و تفكيى بروتئين در سيالات زيستى بسيار يِيجيده مىباشد كه به دليل حضور انواع بسيارى از يروتئينها در

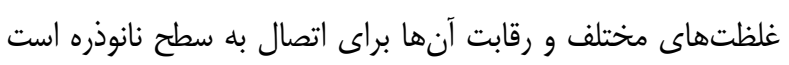

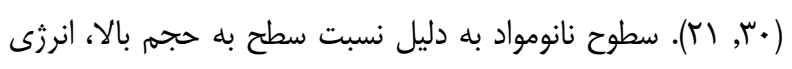

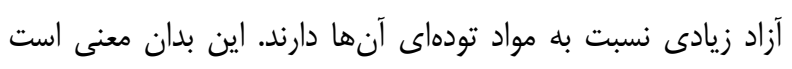

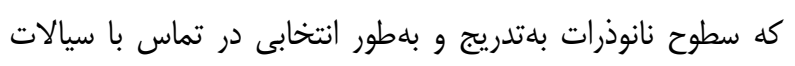

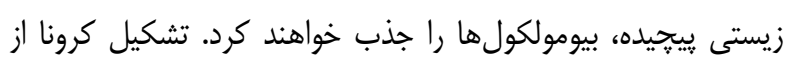

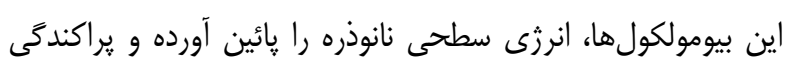
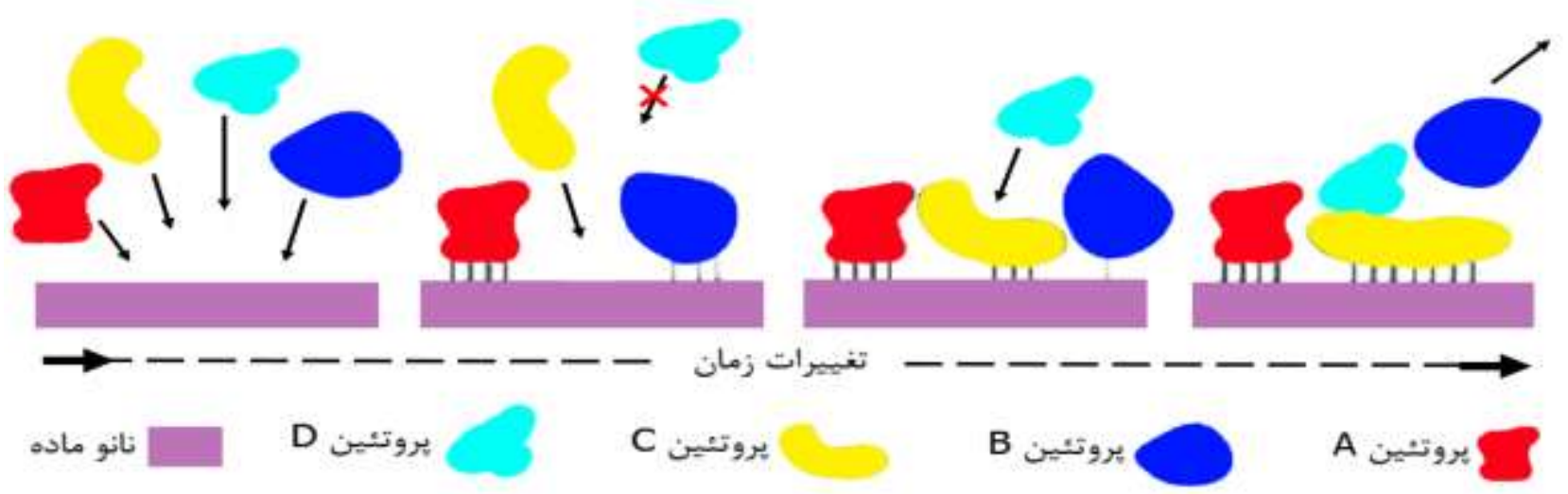

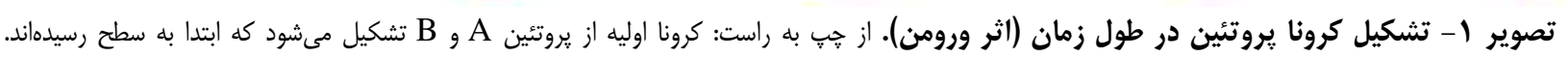

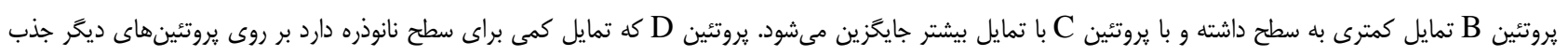



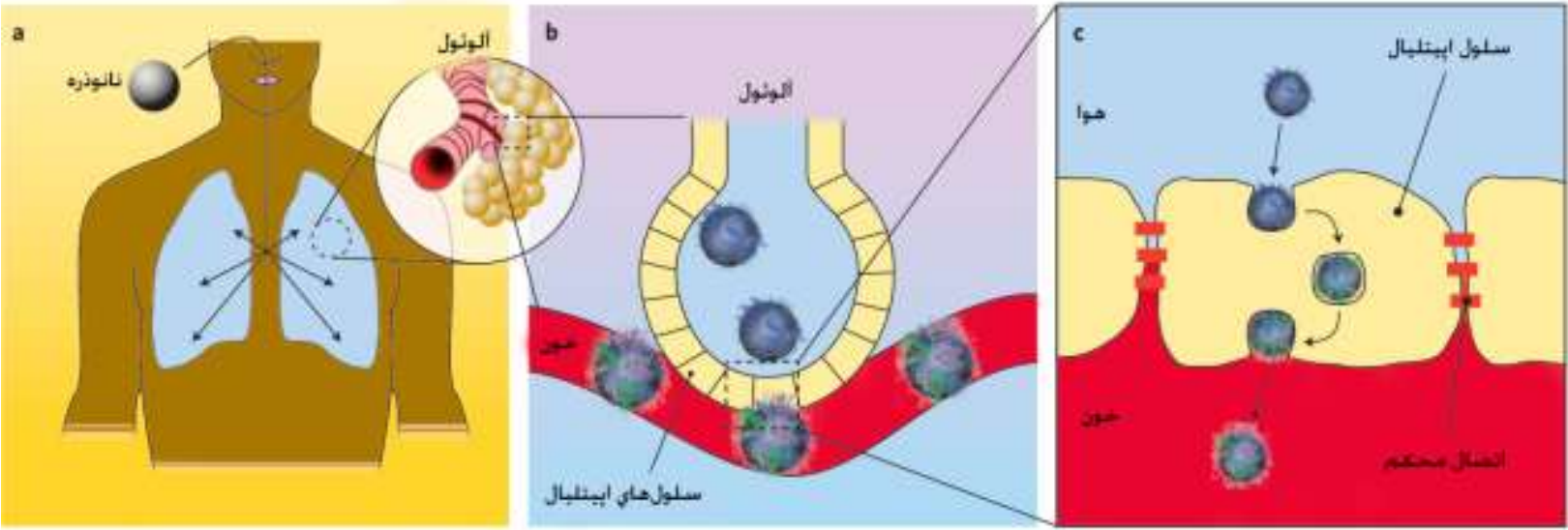

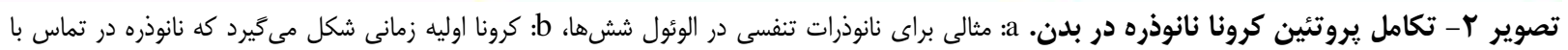

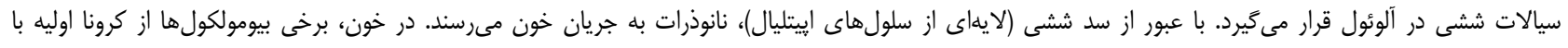

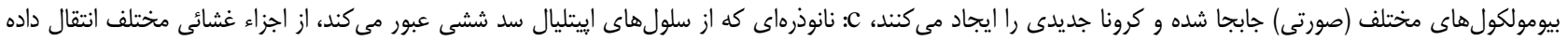

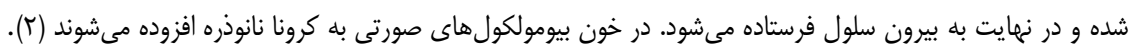

مىيابد. پِ اين راهكار بايد به كَنهاى طراحى گردد تا توانايى كريز

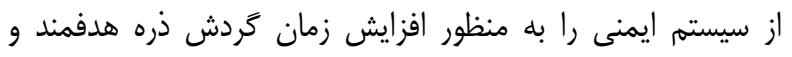
دسترسى خودبهخودى به فرايندهاى انتقال درون سلولى داشته باشد.

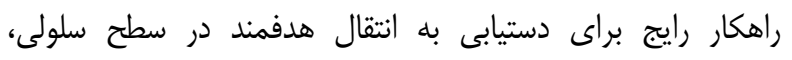
عاملدار كردن سطح نانوذره با بيومولكولهايى است كه به بانه كيرندهاى اختصاصى بيان شده در سطح سلول وارد واكنش مىشوند. مطالعات نشان مىدهند كه افزايش جذب نانوذرات در سلولها به دنبال انتقال هدفمند و شناسايى گيرنده سلولى خاصى رخد مىدهد كه منجر به جذب و رهايش دارو در ناحيه تومورى خواهد شد. ليكن مكانيسم هدف ميرى هميشه استفاده نمى مشود و انتقال غيرفعال بدون نياز به عامل هدفگيرى انجام مىشود، با توجه به مديه

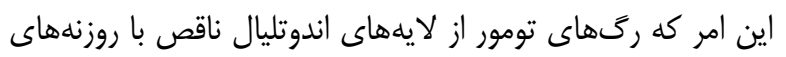

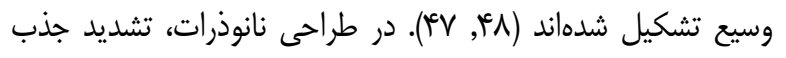

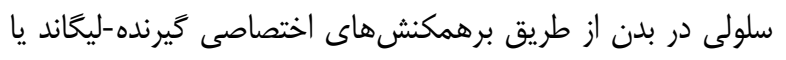
كتترل توزيع زيستى نانوذرات در بدن مورد توجه است كه براى بردي

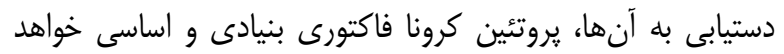

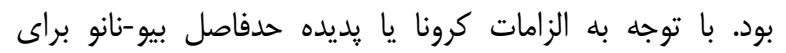

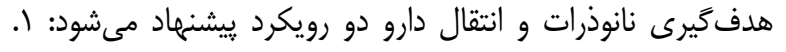
مهندسى سطح در ارتباط با طراحى حدفاصلى كه حداقل

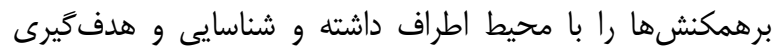

جذب بروتئين نيازمند برهمكنش مستقيم با سطح نانومواد نمىباشد؛ بلكه مىتواند از طريق برهمكنش يروتئين - يروتئين انجام

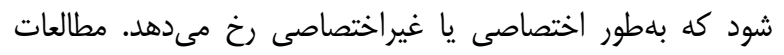
نشان داده است كه تشكيل سريع كرونا يروتئينى به دنبال قرار

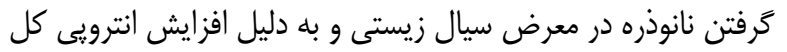

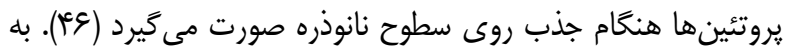
غير از يروفايل يروتئينى در محيط زيستى حاوى نانوذرات، تشكيل

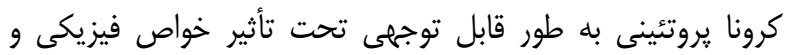

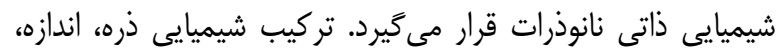

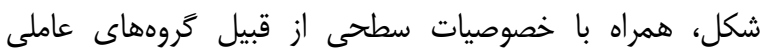
سطحى، بار سطحى و آب گريزى و نيز صافى سطح و انحنا، تعيين

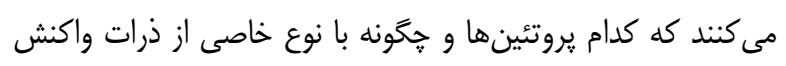
دهند. با اين وجود، مشخصه سينتيك نانوذرات مىبايست به به طور دقيق تعيين كَردد تا بتوان به فعاليت زيستى مورد نظر دست يافت.

\section{r. طراحى حدفاصل نانوذره-بيومولكول براى انتقال هدفمند و كاربرد درمانى}

هدفمندى رويكردى است كه به منظور افزايش اختصاصيت اثر

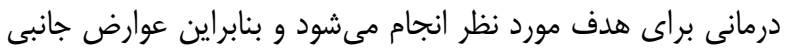
مرتبط با تجمع غيراختصاصى در ديخر اندامها يا اجزاء سلولى كاهش فارس 
تاكنون تلاشهاى زيادى در جهت شناسايى يروتئينهايى با

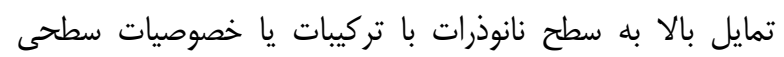

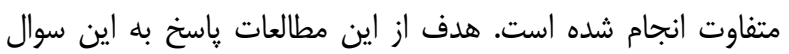

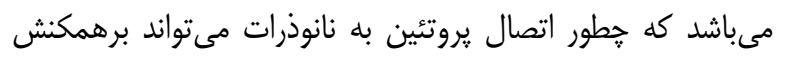

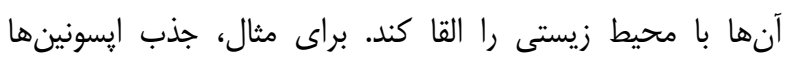

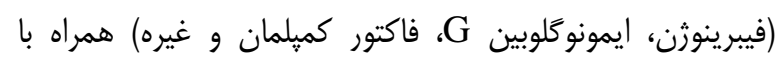

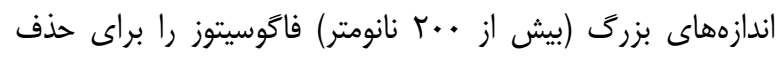

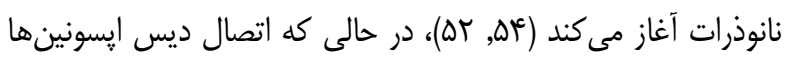

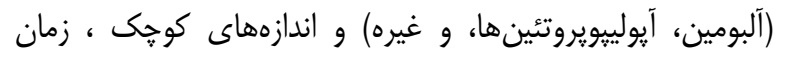

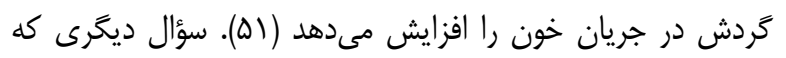

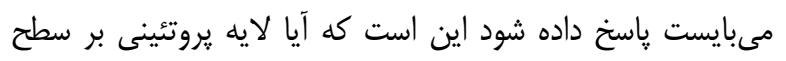

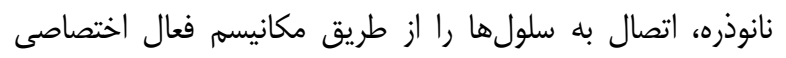

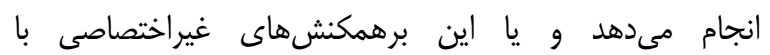

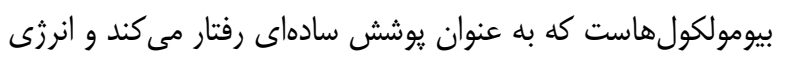

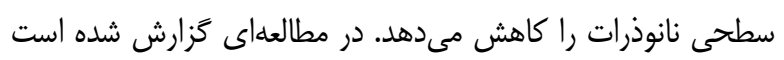
كه نانوذرات يلى استيرن با سطوح اصلاح شده متفاوت، كرونات راهن يروتئينهاى اختصاصى مختلفى دارند؛ اين منجر به ارتباط متفاوت

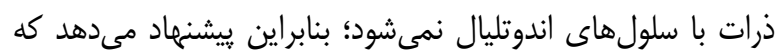

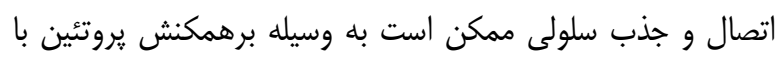
كيرندهاى اختصاصى نباشد. در اين مطالعه، فراوانترين يروتئينها

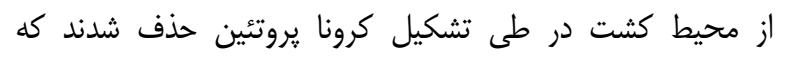

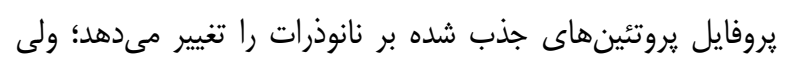

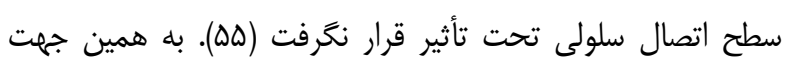

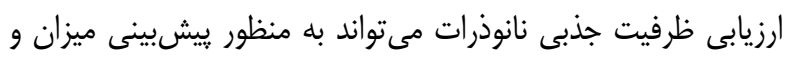
توان برهمكنشهاى سلولى با نانوذرات بسيار كارآمد و سودمند باشد.

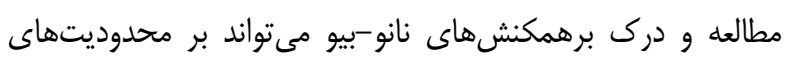
موجود غلبه كرده و با اصلاح سطح و ساختار نانوذرات، اتصال

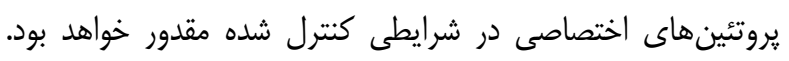

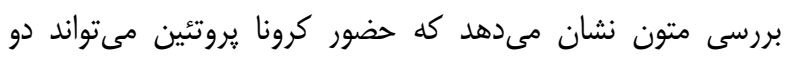

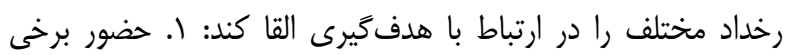

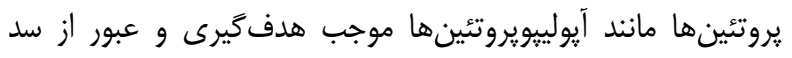

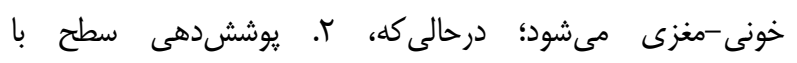

اختصاصى را انجام مىدهد. r. بهرهورى از يروتئين كرونا براى

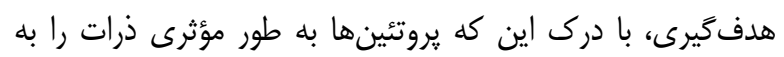
نقطه دلخواه انتقال مىدهند. مطالعهاى كليدى در اين زمينه نشان

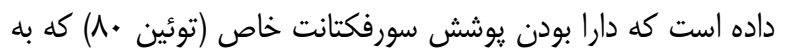
طور خودبهخودى به آيولييويروتئين E متصل مىشود در انتقال دارو به مغز مؤثر بوده و به عنوان ذرهاى با سطح مهندسى شده به به طور

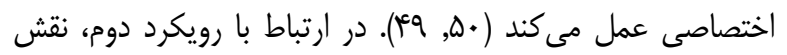

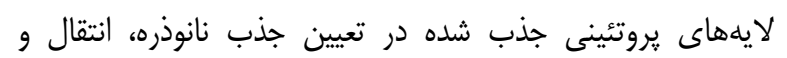

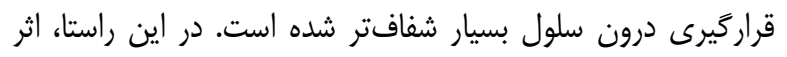

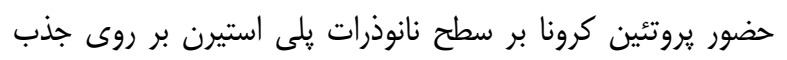

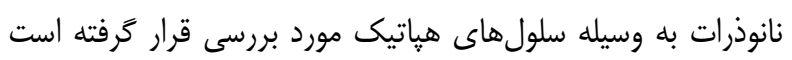
(D)(مانى كه نانوذرات در غياب سرم در محيط كشت استفاده مىشوند، جذب قابل توجهى مشاهده مىشود؛ درحالى كه در حضور

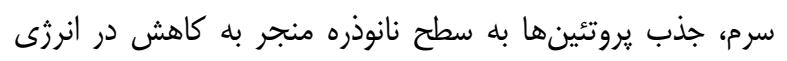

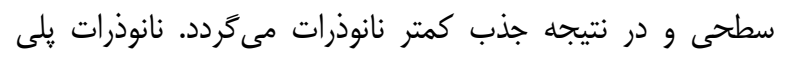

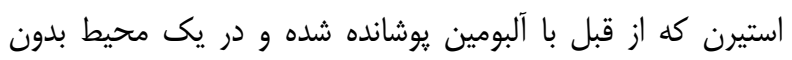

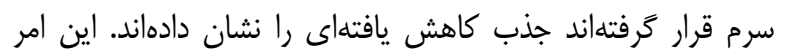
ييشنهاد مى دهد حضور يروتئين ها از اتصالات غير اختصاصى نانوذرات به سطح سلول جلوكيرى مى كند (DT). مطالعه مشابه ديغرى تأييد

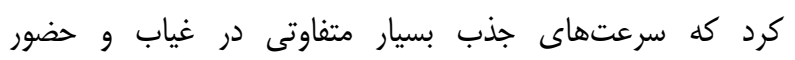

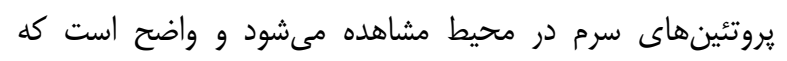
تفاوتها در تركيب يا منبع يروتئينهاى سرمى مى توانند اثرات قابل دمان

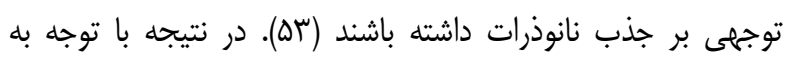

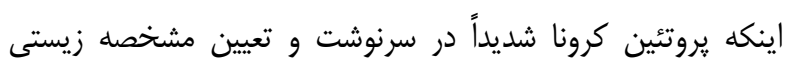

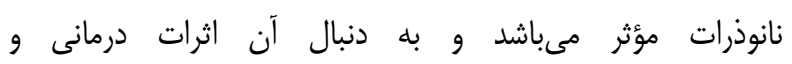

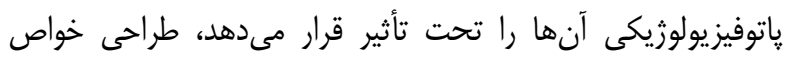

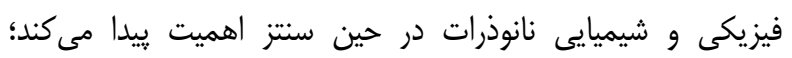

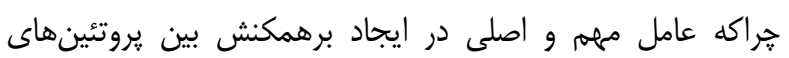

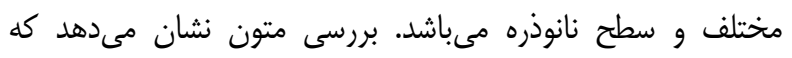

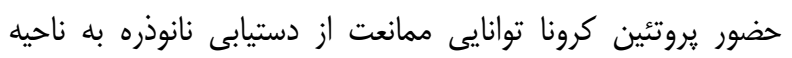

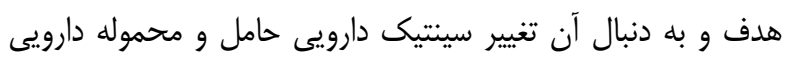

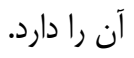


جايخاه فعال روى ليگاند بايد در حالتى صحيح و آرايشى سه بعدى براى بهينه سازى اتصال به كيرنده عرضه شود.

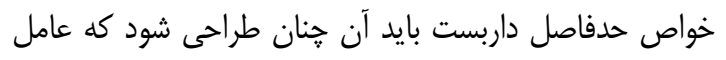

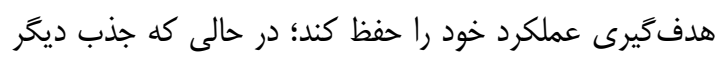
بيومولكولها در محيط اطراف، عامل هدفَّيرى را نبوشاند يا

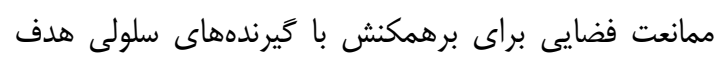

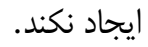
به منظور افزايش زمان كردش و تشديد ميزان دسترسى به ناحيه هدف، ذره بايد قادر به گريز از سيستم ايمنى باشد.

با اين وصف، به منظور بهينه كردن برهمكنش در بدن، نياز به

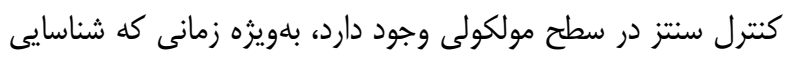
مولكولى در غشاء سلولى مدنظر مىباشد. محدوديتهاى اصلى براى

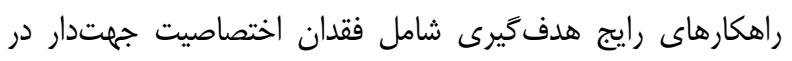
روشهاى شيميايى اتصال و عدم توجه به اثر ديخر يروتئينهاى رناى متصل شونده به نانوذره هستند. كنترل دقيق جهت يروتئين در سطح

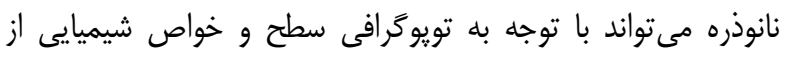

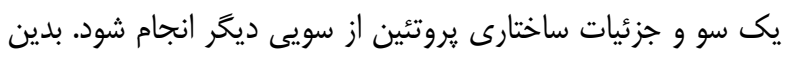
منظور، جهتدهى كنترل شده مى تواند از طريق تكنيكهاى يِيشرفته

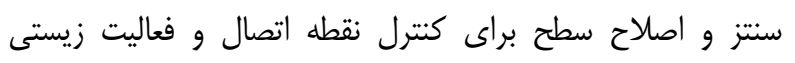

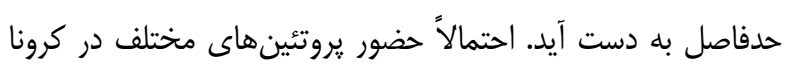
نانوذره-ِيروتئين مى تواند منبع مسيرهاى جذبى جائ جايخزين باشد.

\section{روشهاى آناليتيكى براى ارزيابى كرونا}

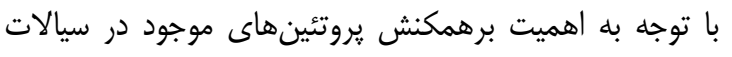

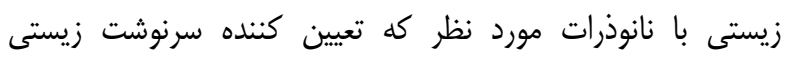

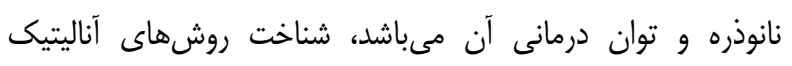

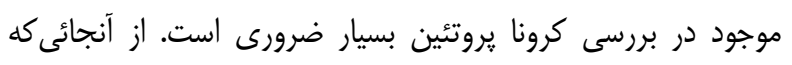

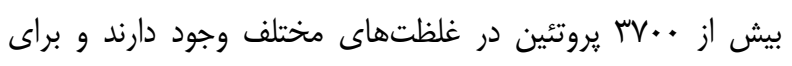
اتصال به سطح نانوذره رقابت مى كنند، مطالعه برهمكنش بروتئينها (تعيين سرعتهاى اتصال، تمايلات، استوكيومترىهاى اتصال

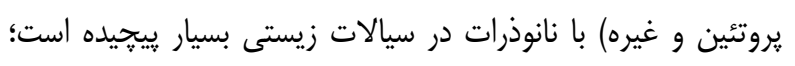

يروتئينهاى مختلف مى تواند موجب عدم دسترسى ليخاند به كيرنده

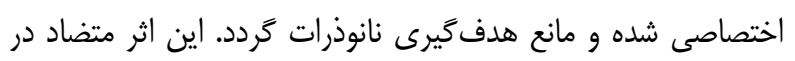

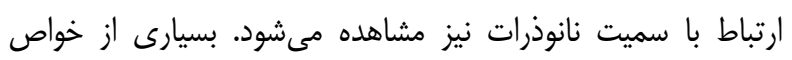

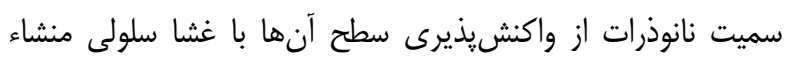

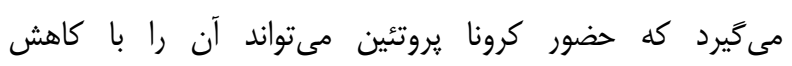
واكنشيذيرى تعديل كند؛ اما در مقابل، جذب يروتئينها بر سطح بردي

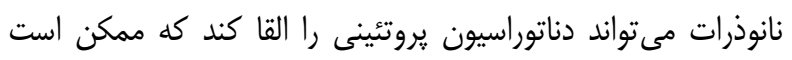
موجب تحريك سيستم ايمنى و پاسخ فيزيوليوزيكى نامطلوب كردد.

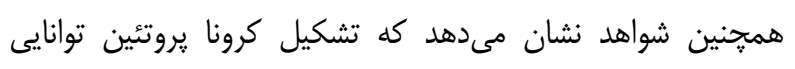

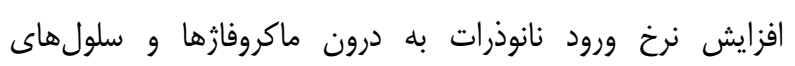

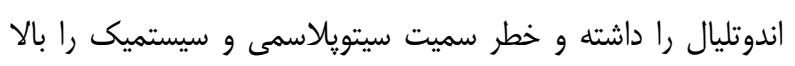

مىبرد (DF).

براساس بحث بالا، در طراحى حدفاصل نانو-بيو براى انتقال

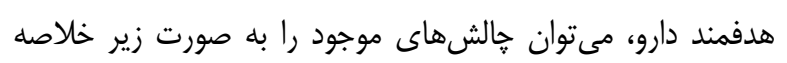
كرد (تصوير ب):
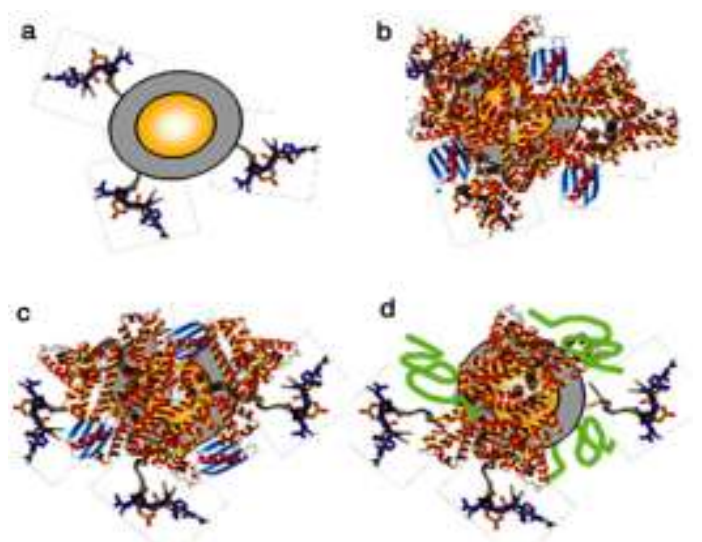

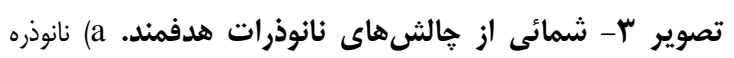

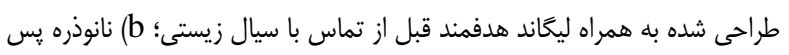

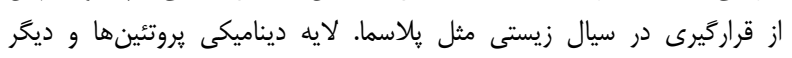

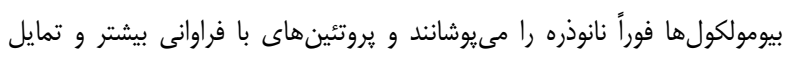

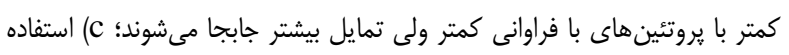

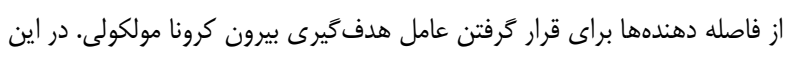

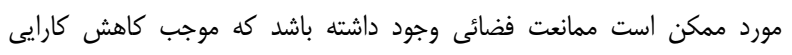

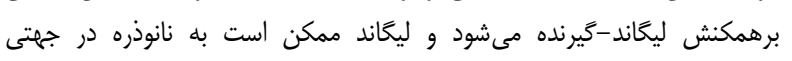

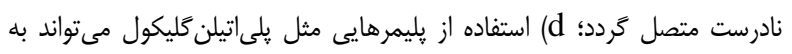

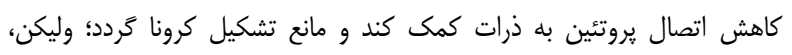

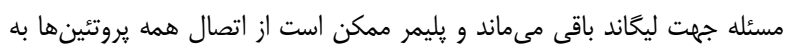
نانوذرات جلوكيرى نكند (ع)ا. 
است تلنشين شوند و به اشتباه به عنوان كرونا يروتئين شناخته شوند؛

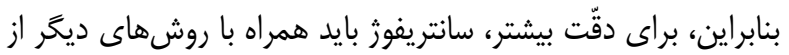
قبيل فيلتراسيون ثلى انجام شود (Tr).

\section{دورنتَ نمايى دورانى}

ساختارهاى ثانويه يروتئين مثل آلفا هليكس و صفحات بتا طيف دو رنغ نمايى حلقوى خاص خود را در ناحيه فرابنفش دارند. روش

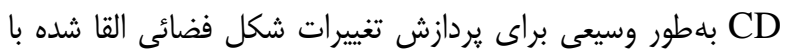

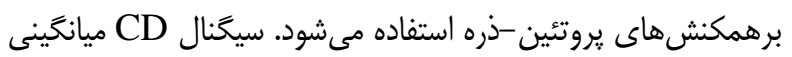

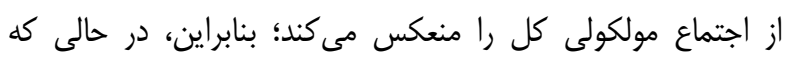

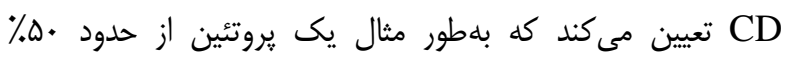

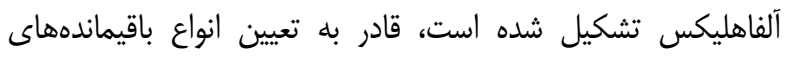

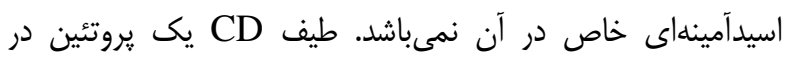

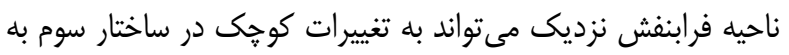

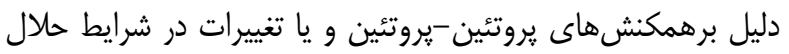

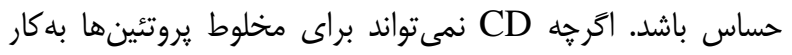
رود، مىتواند اطلاعات مفيدى درباره تغييرات ساختارى يروتئين جذب شده بر سطح نانوذره فراهم كند (• (؟).

\section{كالريمترى تيتر اسيون ايزوترمال}

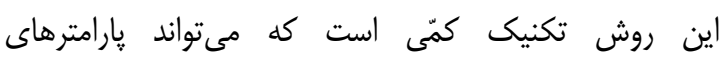
ترموديناميك را در محلول از قبيل تمايل اتصال، استوكيومترى لكئي

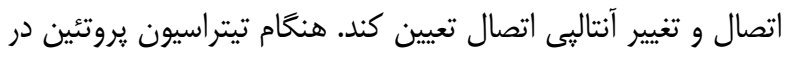

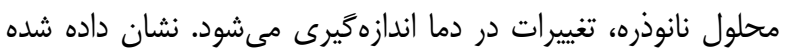

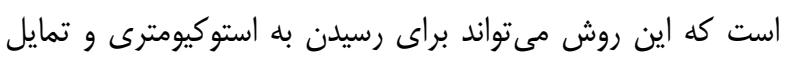

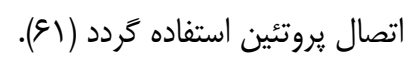

UV-) ' (r).

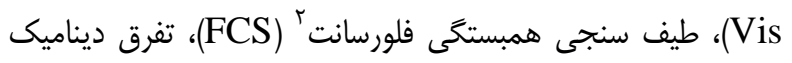

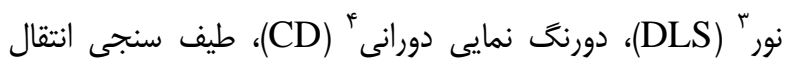

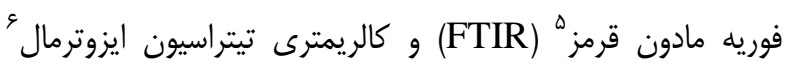

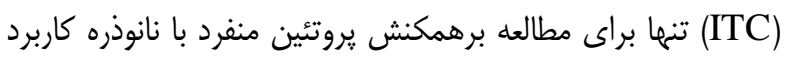

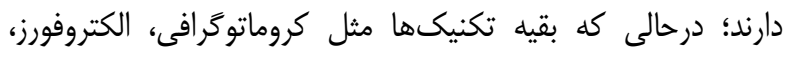

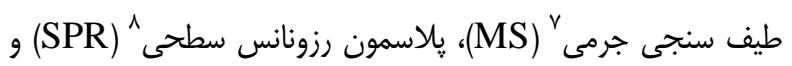

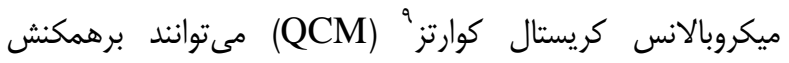

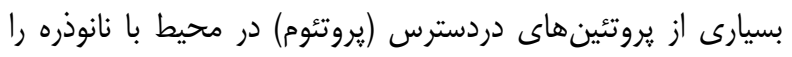

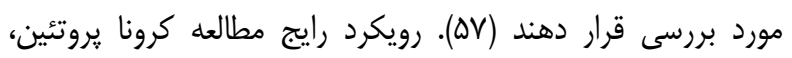

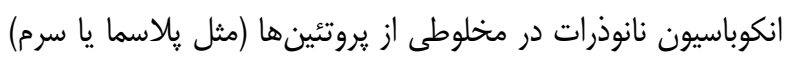

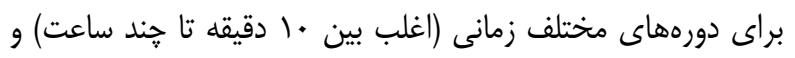

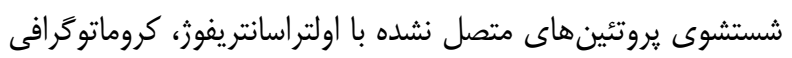

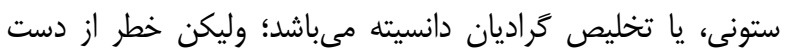
رفتن يروتئينهاى متصل در اين شستشوها وجود دارد. كرونا بروتئين به وسيله پارامترهاى مختلفى از قبيل ضخامت، دانسيته، شناسه

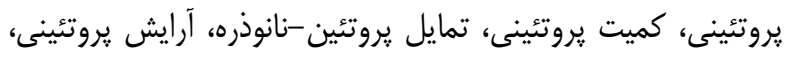

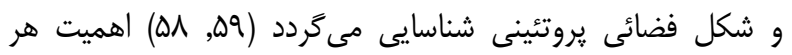
يارامتر و نيز تكنيكهاى مشخصهيابى براى هريك از آنها در جدول ا خلاصه شدهاند. سانتر يفوز

بيشتر مطالعات كرونا يروتئين با انكوباسيون نانوذرات درون هِاسماى خون آغاز مىشود. در اين روش، مدت زمان شستشو، تعداد مراحل، و حجم محلول مىتواند بر لايه كرونا يروتئين اثر بحذارند. مشكل موجود در اين روش اين است كه در طى سانتريفوز مراز

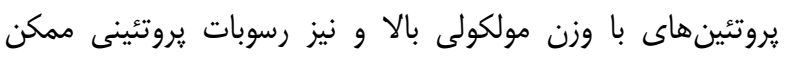

\footnotetext{
${ }^{1}$ Ultraviolet-visible spectroscopy

${ }^{2}$ Fluorescence correlation spectroscopy

${ }^{3}$ Dynamic light scattering

${ }^{4}$ Circulr dichroism

${ }^{5}$ Fourier-transform infrared spectroscopy

${ }^{6}$ Isothermal titration calorimetry

${ }^{7}$ Mass spectrometry

${ }^{8}$ Surface plasmon resonance

${ }^{9}$ Quartz crystal microbalance
} 
جدول ا - تكنيكهاى مطالعه بارامترهاى مؤثر بر ساختار و تركيب كرونا بروتئين.

\begin{tabular}{|c|c|c|}
\hline تكنيكها & اثرات بر نانوسيستمها & يارامتر كرونا \\
\hline DLS ،DCS ،SEC ،TEM & اثر بر اندازه هيدروديناميك نانوذره & ضخامت و دانسيته \\
\hline PAGE ،LC-MS/MS & اثر بر آرايه برهمكنشهاى زيستى & شناسه و كميت \\
\hline 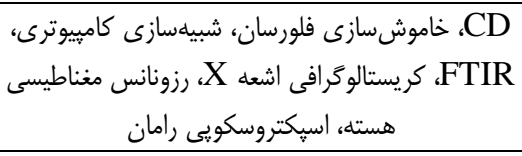 & اثر بر فعاليت يك يروتئين و برهمكنش آنآن & شكل فضائى \\
\hline SEC SPR ،ITC & اثر بر برهمكنش بيوفيزيكى يا انتقال به بخش فيزيولوزيكى جديد & تمايل \\
\hline 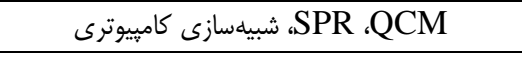 & اثر تبادلات با محيط زيستى و نحوه اتصال يروتئينها & سينتيك اتصال \\
\hline
\end{tabular}

TEM: Transmission Electron Microscopy; SEC: Size-exclusion Chromatography; DCS: Differential Centrifugal Sedimentation; DLS: Dynamic Light Scattering; LC-MS/MS: Liquid Chromatography-Mass Spectrometry; PAGE: Polyacrylmide Gel Electrophoresis; CD: Circular Dichroism; ITC: Isothermal Titration Calorimetry; SPR: Surface Plasmon Resonance; QCM: Quartz Crystal Microbalance. (D৭).

\section{اسبكتروسكويى فلورسانس}

اين روش كه اسيكتروفلورومترى نيز ناميده مىشود، براساس تحريك الكترونها از سطح پايه به سطوح بالاتر انرزى يا همان

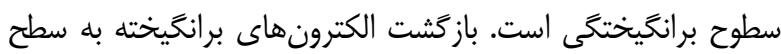

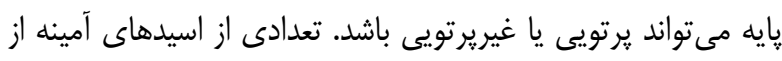

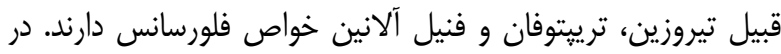
مطالعه برهمكنشهاى نانوذره-يروتئين، نانوذره يا يروتئين و يا حتى تئي

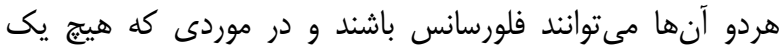
فلورسان نيست، يك رنخ فلورسانس بايد به سيستم افزوده كردد. از آنجاكه نشاندار كردن فلورسانس مىتواند شكل فضائى يا ساختار

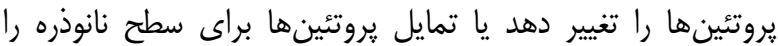

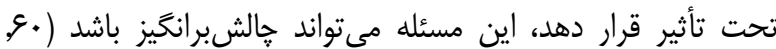

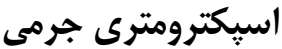

اين تكنيك امروزه ابزارى قوى و ضرورى در علوم زيستى و

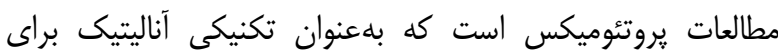
شناسايى شناسههاى يروتئينى استفاده مىشود. در اين روش معمولاً نمونه به يِيتيدهاى كوجى هضم مى گردد كه يونيزه و قطعه قطعه شدهاند. MS مى تواند اطلاعات كمّى و كيفى از مخلوط يروتئينى

\footnotetext{
${ }^{2}$ Mass Spectrometry
}

\section{الكتروفورز زل يلى آكريلاميد-سديم دودسيل سولفونات'}

(SDS-PAGE)

الكتروفورز روشى شناخته شده براى جداسازى و آناليز

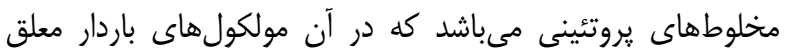
شده در يك سيال تحت ميدان الكتريكى حركت مى كنند. الكتروفورز موئين و الكتروفورزهاى زلى تكبعدى و دو بعدى روشهاى ريد رايج براى آناليز كمبلكسهاى نانوذره-بروتئين هستند. اين روش

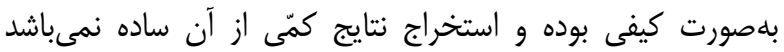

\section{اسبكتروسكويـى فر ابنفش-مرئى}

اين روش بر مبناى اندازهيرى نسبت نور عبور كرده به نور

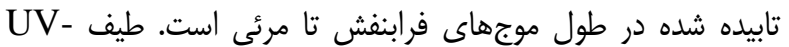
مىتواند بلصورت جذبى يا عبورى نشان داده شود. جذب لمن

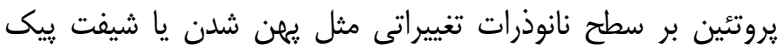

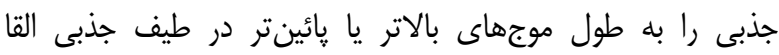

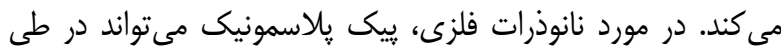
جذب يروتئين بر سطح نانوذره يردازش كردد كه به شرايط سطح و محيط نانوذره بسيار حساس است (بو).

\footnotetext{
${ }^{1}$ Sodium dodecyl sulphate-polyacrylamide gel electrophoresis
} 


\section{رسوبَّذارى سانتريفوزى تمايلى}

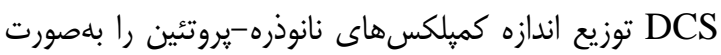
نيمه كمّى در حضور مخلوط :بروتئينياندازميرى مىنمايد. در مطالعهاى ساختار و קِايدارى كميلكسهاى يروتئينى-نانوذره در

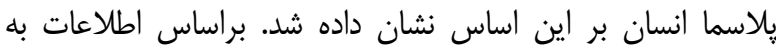

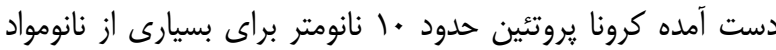

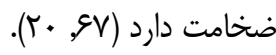

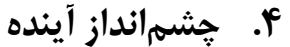

يوشش غيرقابل اجتناب سطوح نانوذرات به وسيله بروتئينها

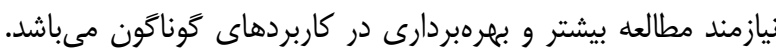
در اين راستا درك عميقى از مكانيسم تشكيل كرونا يروتئين و اثرات

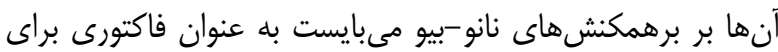
تنظيم تركيب شيميايى، اندازه، شكل و خواص سطحى نانو نانوذرات مورد توجه قرار گيرد تا بدين صورت يروتئينهاى خاصى به سطح نانوذره اتصال يابند. براى يك كاربرد بالينى مشخص، اتصال

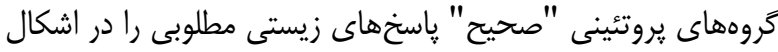
مختلف شامل انتقال و جذب هدفمند سلولى به واسطه گيرنده، زمان

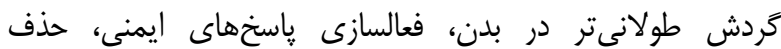
بيومولكولهاى پاتولوزيك و نيز كاهش اثرات سمى ناخواسته

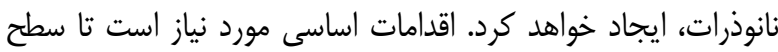

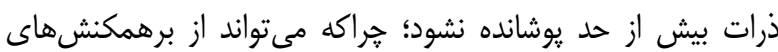
بين يروتئينهاى متصل به ذره و گيرندههاى سلولى ممانعت كند.

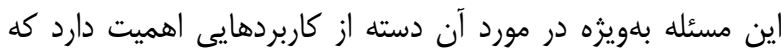
وابسته به جذب سلولى و نيز تحريك پاسخهاى ايمنى هستند. اخرجه

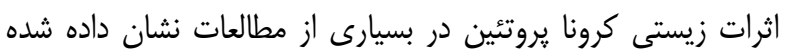

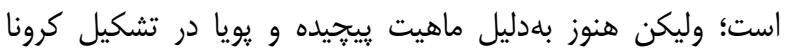

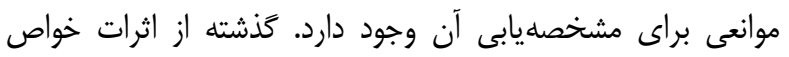
فيزيكوشيميايى نانوذرات و مشخصات سيال زيستى بر تشكيل كرونا،

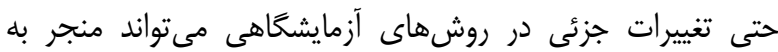
تغييرات قابل توجهى در تركيب كرونا تشكيل شده شود كه به نوبيه

\footnotetext{
${ }^{3}$ Differential Centrifugal Sedimentation
}

فراهم كند و بلطور موفقيتآميزى براى شناسايى كرونا بروتئينها با

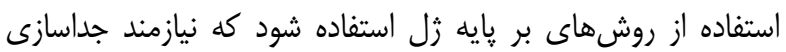

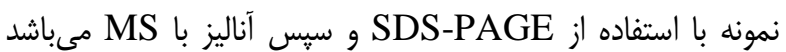

\section{اسبكتروسكويبىهاي مادون قرمز انتقال فوريه و رامان}

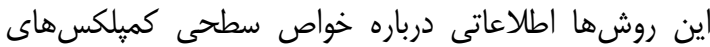

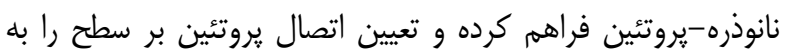

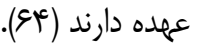

\section{رزونانس مغناطيسى هسته'}

اين روش در تعيين شكل فضائى يروتئينها قبل و بعد از اتصال

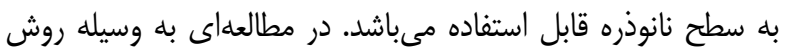

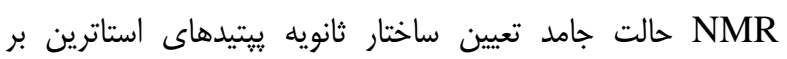

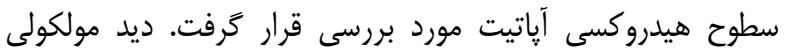
فراهم شده با اين مطالعات منجر به طراحى يِيتيدهاى الحاقى شبهزيستى شده است كه از مكانيسم شناسايى كريستالى براى نمايش توالىهاى فعال زيستى ديناميك و در دسترس از سطح هيدروكسى آياتيت بهره مىبرند (90).

\section{كريستالوكَرافى اشعه}

اين روش بلهور معمول براى تعيين جُخَونكى برهمكنش دارو

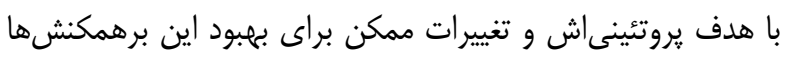

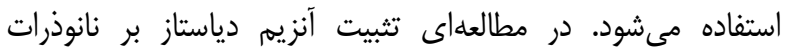

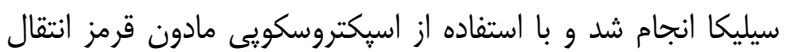

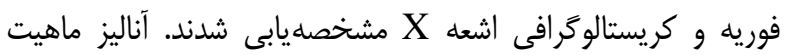

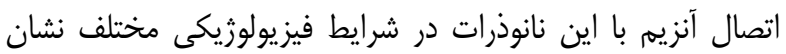

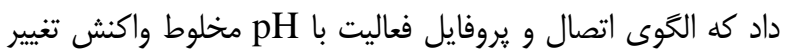

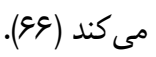

\footnotetext{
${ }^{1}$ Nuclear magnetic resonance

${ }^{2} \mathrm{X}$-ray crystallography
} 


\section{نتيجه Fيرى}

براساس مطالب ذكر شده در اين مطالعه و مرورى بر منابع،

مىتوان نتيجه گرفت كه خواص فيزيكى و شيميايى نقش بسيار مهمى در توزيع زيستى نانوذرات ايفا كرده و جذب يروتئينهاى مختلف بر سطح نانوذرات و تشكيل يروتئين كرونا مىتواند توزيع زيستى، زيست سازگارى و كارايى درمانى نانوذرات را تحت تأثير قرار دهد. پس مشخصهيابى نانوذرات و بررسى پايدارى آنها در شرايط فيزيولوزيك بسيار ضرورى مىباشد. يروتئين كرونا مىتواند موجب حذف سريع نانوذرات از بدن توسط سيسته ايمنى شوند و يا انتقال نانوذره به بافت هدف را تسهيل نمايد. اين رفتار دوگانه موجب شده است كه امروزه برهمكنش نانوذره-يروتئين بسيار مورد توجه قرار گرفته و در طراحى نانوسامانههاى دارويى، مشخصه زيستى نانوذرات در كنار مشخصdهاى فيزيكى و شيميايى مورد بررسى قرار مى

\section{تقدير و تشكّر}

از همكارى معاونت محترم تحقيقات و مركز سلولى مولكولى دانشگاه علوم يزشكى بيرجند قدردانى مىشود.

تضاد منافع

نويسندگان مقاله اعلام مىدارند كه هيج گونه تضاد منافعى در

$$
\text { يزوهش حاضر وجود ندارد. }
$$

خود ياسخهاى زيستى را تغيير مىدهد. با اين وجود، كشف كرونا يروتئين و تأثيرات قطعى آن بر سرنوشت زيستى نانوذرات، مهندسى نانوذرات را براى عملكردهاى زيستى اختصاصى امكانيذير مى كند. به منظور تشديد ايمنى و كارايى كاربرد نانوذره، لازم است كه جَگونكَى تشكيل كروناهاى يروتئينى و نحوه عمل آنها در تنظيه فعاليت نانوذرات مشخص به درستى مطالعه گردند. مشخصههاى شكل فضائى يروتئينهاى كرونايى در نانوذرات مختلف معيارى تعيينكننده مىباشد كه مىبايست مدنظر قرار گَيرد. تاكنون يافتهاى بهدست آمده از ويثگى هاى ساختارى يروتئينهاى كرونا در سطح اتمى براى ارزيابى و مطالعه كامل سيستم كرونا-نانوذره كافى نبوده است؛ بنابراين مطالعه جامعى بر روى يروتئينهاى مختلف شركت كننده در ساختار كرونا و نيز بررسى محيطهاى مختلف در بدن مورد نياز است تا بتوان ميان اصول يايهاى و كاربرد نهايى ارتباطى كارآمد برقرار كرد. براين اساس، درك كميلكس يروتئينكرونا و برهمكنشهاى آن براى ييش بينى سرنوشت نانوذرات در بدن بعد از استعمال از قبيل توزيع زيستى، دسترسى زيستى، پاسخها و سميت از اهميت زيادى برخوردار است. همجنين دستخاههاى آناليتيك نيز بلمنظظور مشخصهيابى كرونا يروتئين از جنبههاى مختلف نياز به ييشرفت بيشترى دارند.

1- Park SJ. Protein-nanoparticle interaction: corona formation and conformational changes in proteins on nanoparticles. Int J Nanomedicine. 2020; 15: 5783-5802. DOI: 10.2147/IJN.S254808

2- Monopoli MP, Åberg C, Salvati A, Dawson KA. Biomolecular coronas provide the biological identity of nanosized materials. Nat Nanotechnol. 2012; 7(12): 779-86. DOI: 10.1038/nnano.2012.207

3- Gunawan C, Lim M, Marquis CP, Amal R. Nanoparticle-protein corona complexes govern the biological fates and functions of nanoparticles. J Mater Chem B. 2014; 2(15): 2060-83. DOI: 10.1039/C3TB21526A

4- Abarca-Cabrera L, Fraga-García P, Berensmeier S. Bio-nano interactions: binding proteins, polysaccharides, lipids and nucleic acids onto magnetic nanoparticles. Biomater Res. 2021; 25(1): 1-18. DOI: 10.1186/s40824-021-00212$\mathrm{y}$

5- Prapainop K, Witter DP, Wentworth Jr P. A chemical approach for cell-specific targeting of nanomaterials: smallmolecule-initiated misfolding of nanoparticle corona proteins. J Am Chem Soc. 2012; 134(9): 4100-3. DOI: $10.1021 / \mathrm{ja} 300537 \mathrm{u}$ 
6- Deng ZJ, Liang M, Monteiro M, Toth I, Minchin RF. Nanoparticle-induced unfolding of fibrinogen promotes Mac-1 receptor activation and inflammation. Nat Nanotechnol. 2011; 6(1): 39-44. DOI: 10.1038/nnano.2010.250

7- Deng ZJ, Liang M, Toth I, Monteiro MJ, Minchin RF. Molecular interaction of poly (acrylic acid) gold nanoparticles with human fibrinogen. ACS nano. 2012; 6(10): 8962-9. DOI: 10.1021/nn3029953

8- Sedighi M, Rahimi F, Shahbazi M-A, Rezayan AH, Kettiger H, Einfalt T, et al. Controlled Tyrosine Kinase Inhibitor Delivery to Liver Cancer Cells by Gate-Capped Mesoporous Silica Nanoparticles. ACS Appl. Bio Mater. 2020; 3(1): 239-51. DOI: 10.1021/acsabm.9b00772

9- Dell'Orco D, Lundqvist M, Oslakovic C, Cedervall T, Linse S. Modeling the time evolution of the nanoparticleprotein corona in a body fluid. PloS one. 2010; 5(6): e10949. DOI: 10.1371/journal.pone.0010949

10- Hamad-Schifferli K. How can we exploit the protein corona? Nanomedicine (Lond). 2013; 8(1): 1-3. DOI: $10.2217 / \mathrm{nnm} .12 .179$

11- Lynch I, Dawson KA. Protein-nanoparticle interactions. Nanotoday. 2008; 3(1-2): 40-7. DOI: 10.1016/S17480132(08)70014-8.

12- Nel AE, Mädler L, Velegol D, Xia T, Hoek EM, Somasundaran P, et al. Understanding biophysicochemical interactions at the nano-bio interface. Nat Mater. 2009; 8(7): 543-57. DOI: 10.1038/nmat2442

13- Cedervall T, Lynch I, Foy M, Berggård T, Donnelly SC, Cagney G, et al. Detailed identification of plasma proteins adsorbed on copolymer nanoparticles. Angew Chem Int Ed Engl. 2007; 46(30): 5754-6. DOI: $10.1002 /$ anie. 200700465

14- Kuznetsova N, Vodovozova E. Differential binding of plasma proteins by liposomes loaded with lipophilic prodrugs of methotrexate and melphalan in the bilayer. Biochemistry (Mosc). 2014; 79(8): 797-804. DOI: $10.1134 /$ S0006297914080070

15- Vroman L. Effect of adsorbed proteins on the wettability of hydrophilic and hydrophobic solids. Nature. 1962; 196(4853): 476-7. DOI: 10.1038/196476a0

16- Hirsh SL, McKenzie DR, Nosworthy NJ, Denman JA, Sezerman OU, Bilek MM. The Vroman effect: competitive protein exchange with dynamic multilayer protein aggregates. Colloids Surf B Biointerfaces. 2013; 103: 395-404. DOI: $10.1016 /$ j.colsurfb.2012.10.039

17- Zhang H, Burnum KE, Luna ML, Petritis BO, Kim JS, Qian WJ, et al. Quantitative proteomics analysis of adsorbed plasma proteins classifies nanoparticles with different surface properties and size. Proteomics. 2011; 11(23): 456977. DOI: $10.1002 /$ pmic.201100037

18- Ferreira SA, Oslakovic C, Cukalevski R, Frohm B, Dahlbäck B, Linse S, et al. Biocompatibility of mannan nanogel—safe interaction with plasma proteins. Biochim Biophys Acta. 2012; 1820(7): 1043-51. DOI: 10.1016/j.bbagen.2012.04.015

19- Sedighi M, Sieber S, Rahimi F, Shahbazi M-A, Rezayan AH, Huwyler J, et al. Rapid optimization of liposome characteristics using a combined microfluidics and design-of-experiment approach. Drug Deliv Transl Res. 2019; 9(1): 404-13. DOI: 10.1007/s13346-018-0587-4

20- Walczyk D, Bombelli FB, Monopoli MP, Lynch I, Dawson KA. What the cell "sees" in bionanoscience. J Am Chem Soc. 2010; 132(16): 5761-8. DOI: 10.1021/ja910675v

21- Tellechea E, Wilson KJ, Bravo E, Hamad-Schifferli K. Engineering the interface between glucose oxidase and nanoparticles. Langmuir. 2012; 28(11): 5190-200. DOI: 10.1021/la2050866

22- Aggarwal P, Hall JB, McLeland CB, Dobrovolskaia MA, McNeil SE. Nanoparticle interaction with plasma proteins as it relates to particle biodistribution, biocompatibility and therapeutic efficacy. Adv Drug Deliv Rev. 2009; 61(6): 428-37. DOI: 10.1016/j.addr.2009.03.009

23- Choi HS, Ashitate Y, Lee JH, Kim SH, Matsui A, Insin N, et al. Rapid translocation of nanoparticles from the lung airspaces to the body. Nat Biotechnol. 2010; 28(12): 1300-3. DOI: 10.1038/nbt.1696

24- Schleh C, Rothen-Rutishauser B, Kreyling WG. The influence of pulmonary surfactant on nanoparticulate drug delivery systems. Eur J Pharm Biopharm. 2011; 77(3): 350-2. DOI: 10.1016/j.ejpb.2010.12.025 
25- Walkey CD, Chan WC. Understanding and controlling the interaction of nanomaterials with proteins in a physiological environment. Chem Soc Rev. 2012; 41(7): 2780-99. DOI: 10.1039/C1CS15233E

26- Tenzer S, Docter D, Rosfa S, Wlodarski A, Kuharev Jr, Rekik A, et al. Nanoparticle size is a critical physicochemical determinant of the human blood plasma corona: a comprehensive quantitative proteomic analysis. ACS Nano. 2011; 5(9): 7155-67. DOI: 10.1021/nn201950e

27- Sacchetti C, Motamedchaboki K, Magrini A, Palmieri G, Mattei M, Bernardini S, et al. Surface polyethylene glycol conformation influences the protein corona of polyethylene glycol-modified single-walled carbon nanotubes: potential implications on biological performance. ACS Nano. 2013; 7(3): 1974-89. DOI: 10.1021/nn400409h

28- Mahmoudi M, Monopoli MP, Rezaei M, Lynch I, Bertoli F, McManus J, et al. The protein corona mediates the impact of nanomaterials and slows amyloid beta fibrillation. ChemBioChem. 2013; 14(5): 568-72. DOI: $10.1002 /$ cbic.201300007

29- Tsuda A, Konduru NV. The role of natural processes and surface energy of inhaled engineered nanoparticles on aggregation and corona formation. NanoImpact. 2016; 2: 38-44. DOI: 10.1016/j.impact.2016.06.002

30- Keighron JD, Keating CD. Enzyme: nanoparticle bioconjugates with two sequential enzymes: stoichiometry and activity of malate dehydrogenase and citrate synthase on Au nanoparticles. Langmuir. 2010; 26(24): 18992-9000. DOI: $10.1021 / \mathrm{la} 1040882$

31- Ganji N, Bothun GD. Albumin protein coronas render nanoparticles surface active: consonant interactions at airwater and at lipid monolayer interfaces. Environ Sci: Nano. 2021; 8(1): 160-73. DOI: 10.1039/D0EN00934B

32- Lu X, Xu P, Ding H-M, Yu Y-S, Huo D, Ma Y-Q. Tailoring the component of protein corona via simple chemistry.Nat Commun. 2019; 10(1): 1-14. DOI: 10.1038/s41467-019-12470-5

33- Casals E, Pfaller T, Duschl A, Oostingh GJ, Puntes V. Time evolution of the nanoparticle protein corona. ACS Nano. 2010; 4(7): 3623-32. DOI: 10.1021/nn901372t

34- Monopoli MP, Walczyk D, Campbell A, Elia G, Lynch I, Baldelli Bombelli F, et al. Physical- chemical aspects of protein corona: relevance to in vitro and in vivo biological impacts of nanoparticles. J Am Chem Soc. 2011; 133(8): 2525-34. DOI: $10.1021 / \mathrm{ja} 107583 \mathrm{~h}$

35- Deng ZJ, Mortimer G, Schiller T, Musumeci A, Martin D, Minchin RF. Differential plasma protein binding to metal oxide nanoparticles. Nanotechnology. 2009; 20(45): 455101. DOI: 10.1088/0957-4484/20/45/455101

36- Lundqvist M, Stigler J, Elia G, Lynch I, Cedervall T, Dawson KA. Nanoparticle size and surface properties determine the protein corona with possible implications for biological impacts. Proc Natl Acad Sci U S A. 2008; 105(38): 14265-70. DOI: 10.1073/pnas.0805135105

37- Milani S, Baldelli Bombelli F, Pitek AS, Dawson KA, Radler J. Reversible versus irreversible binding of transferrin to polystyrene nanoparticles: soft and hard corona. ACS Nano. 2012; 6(3): 2532-41. DOI: 10.1021/nn204951s

38- Ge C, Du J, Zhao L, Wang L, Liu Y, Li D, et al. Binding of blood proteins to carbon nanotubes reduces cytotoxicity. Proc Natl Acad Sci U S A. 2011; 108(41):16968-73. DOI: 10.1073/pnas.1105270108

39- Dufort S, Sancey L, Coll J-L. Physico-chemical parameters that govern nanoparticles fate also dictate rules for their molecular evolution. Adv Drug Deliv Rev. 2012; 64(2): 179-89. DOI: 10.1016/j.addr.2011.09.009

40- Mahmoudi M, Lynch I, Ejtehadi MR, Monopoli MP, Bombelli FB, Laurent S. Protein- nanoparticle interactions: opportunities and challenges. Chem Rev. 2011; 111(9): 5610-37. DOI: 10.1021/cr100440g

41- Maiorano G, Sabella S, Sorce B, Brunetti V, Malvindi MA, Cingolani R, et al. Effects of cell culture media on the dynamic formation of protein- nanoparticle complexes and influence on the cellular response. ACS Nano. 2010; 4(12): 7481-91. DOI: 10.1021/nn101557e

42- Martel J, Young D, Young A, Wu C-Y, Chen C-D, Yu J-S, et al. Comprehensive proteomic analysis of mineral nanoparticles derived from human body fluids and analyzed by liquid chromatography-tandem mass spectrometry. Anal Biochem. 2011; 418(1): 111-25. DOI: 10.1016/j.ab.2011.06.018 
43- Gasser M, Rothen-Rutishauser B, Krug HF, Gehr P, Nelle M, Yan B, et al. The adsorption of biomolecules to multiwalled carbon nanotubes is influenced by both pulmonary surfactant lipids and surface chemistry. J Nanobiotechnology. 2010; 8(31): 1-9. DOI: 10.1186/1477-3155-8-31

44- Lundqvist M, Stigler J, Cedervall T, Berggard T, Flanagan MB, Lynch I, et al. The evolution of the protein corona around nanoparticles: a test study. ACS Nano. 2011; 5(9): 7503-9. DOI: 10.1021/nn202458g

45- Schleh C, Semmler-Behnke M, Lipka J, Wenk A, Hirn S, Schäffler M, et al. Size and surface charge of gold nanoparticles determine absorption across intestinal barriers and accumulation in secondary target organs after oral administration. Nanotoxicology. 2012; 6(1): 36-46. DOI: 10.3109/17435390.2011.552811

46- Podila R, Chen R, Ke PC, Brown J, Rao A. Effects of surface functional groups on the formation of nanoparticleprotein corona. Appl Phys Lett. 2012; 101(26): 263701. DOI: 10.1063/1.4772509

47- Mahon E, Salvati A, Bombelli FB, Lynch I, Dawson KA. Designing the nanoparticle-biomolecule interface for "targeting and therapeutic delivery". J Control Release. 2012; 161(2): 164-74. DOI: 10.1016/j.jconrel.2012.04.009

48- Shahbazi M-A, Sedighi M, Bauleth-Ramos Ts, Kant K, Correia A, Poursina N, et al. Targeted reinforcement of macrophage reprogramming toward M2 polarization by IL-4-loaded hyaluronic acid particles. ACS Omega. 2018; 3(12): 18444-55. DOI: 10.1021/acsomega.8b03182

49- Kreuter J. Influence of the surface properties on nanoparticle-mediated transport of drugs to the brain. J Nanosci Nanotechnol. 2004; 4(5): 484-8. DOI: 10.1166/jnn.2003.077

50- Kreuter J, Shamenkov D, Petrov V, Ramge P, Cychutek K, Koch-Brandt C, et al. Apolipoprotein-mediated transport of nanoparticle-bound drugs across the blood-brain barrier. J Drug Target. 2002; 10(4): 317-25. DOI: $10.1080 / 10611860290031877$

51- Ogawara K-i, Furumoto K, Nagayama S, Minato K, Higaki K, Kai T, et al. Pre-coating with serum albumin reduces receptor-mediated hepatic disposition of polystyrene nanosphere: implications for rational design of nanoparticles. J Control Release. 2004; 100(3): 451-5. DOI: 10.1016/j.jconrel.2004.07.028

52- Ishida T, Harashima H, Kiwada H. Interactions of liposomes with cells in vitro and in vivo: opsonins and receptors. Curr Drug Metab. 2001; 2(4): 397-409. DOI: 10.2174/1389200013338306

53- Lesniak A, Campbell A, Monopoli MP, Lynch I, Salvati A, Dawson KA. Serum heat inactivation affects protein corona composition and nanoparticle uptake. Biomaterials. 2010; 31(36): 9511-8. DOI: 10.1016/j.biomaterials.2010.09.049

54- Camner P, Lundborg M, Låstbom L, Gerde P, Gross N, Jarstrand C. Experimental and calculated parameters on particle phagocytosis by alveolar macrophages. J Appl Physiol (1985). 2002; 92(6): 2608-16. DOI: 10.1152/japplphysiol.01067.2001

55- Ehrenberg MS, Friedman AE, Finkelstein JN, Oberdörster G, McGrath JL. The influence of protein adsorption on nanoparticle association with cultured endothelial cells. Biomaterials. 2009; 30(4): 603-10. DOI: $10.1016 /$ j.biomaterials.2008.09.050

56- Corbo C, Molinaro R, Parodi A, Toledano Furman NE, Salvatore F, Tasciotti E. The impact of nanoparticle protein corona on cytotoxicity, immunotoxicity and target drug delivery. Nanomedicine (Lond). 2016; 11(1): 81-100. DOI: $10.2217 / \mathrm{nnm} .15 .188$

57- Capriotti AL, Caracciolo G, Cavaliere C, Colapicchioni V, Piovesana S, Pozzi D, et al. Analytical methods for characterizing the nanoparticle-protein corona. Chromatographia. 2014; 77(11-12): 755-69. DOI: 10.1007/s10337014-2677-x

58- Li L, Mu Q, Zhang B, Yan B. Analytical strategies for detecting nanoparticle-protein interactions. Analyst. 2010; 135(7): 1519-30. DOI: 10.1039/C0AN00075B

59- Rahman M, Laurent S, Tawil N, Yahia L, Mahmoudi M. Protein-nanoparticle interactions: Springer; 2013. DOI: $10.1007 / 978-3-642-37555-2$ 
60- Mu Q, Liu W, Xing Y, Zhou H, Li Z, Zhang Y, et al. Protein binding by functionalized multiwalled carbon nanotubes is governed by the surface chemistry of both parties and the nanotube diameter. J Phys Chem C. 2008; 112(9): 3300-7. DOI: 10.1021/jp710541j

61- Lindman S, Lynch I, Thulin E, Nilsson H, Dawson KA, Linse S. Systematic investigation of the thermodynamics of HSA adsorption to $\mathrm{N}$-iso-propylacrylamide/N-tert-butylacrylamide copolymer nanoparticles. Effects of particle size and hydrophobicity.Nano Lett. 2007; 7(4): 914-20. DOI: 10.1021/nl062743+

62- Tessier PM, Jinkoji J, Cheng Y-C, Prentice JL, Lenhoff AM. Self-interaction nanoparticle spectroscopy: a nanoparticle-based protein interaction assay. J Am Chem Soc. 2008; 130(10): 3106-12. DOI: 10.1021/ja077624q

63- Simberg D, Park J-H, Karmali PP, Zhang W-M, Merkulov S, McCrae K, et al. Differential proteomics analysis of the surface heterogeneity of dextran iron oxide nanoparticles and the implications for their in vivo clearance. Biomaterials. 2009; 30(23-24): 3926-33. DOI: 10.1016/j.biomaterials.2009.03.056

64- Xiao Q, Huang S, Qi Z-D, Zhou B, He Z-K, Liu Y. Conformation, thermodynamics and stoichiometry of HSA adsorbed to colloidal CdSe/ZnS quantum dots. Biochim Biophys Acta. 2008; 1784 (7-8) 1020-7. DOI: 10.1016/j.bbapap.2008.03.018

65- Hellstrand E, Lynch I, Andersson A, Drakenberg T, Dahlbäck B, Dawson KA, et al. Complete high-density lipoproteins in nanoparticle corona. FEBS J.. 2009; 276(12): 3372-81. DOI: 10.1111/j.1742-4658.2009.07062.X

66- Prakasham RS, Devi GS, Rao CS, Sivakumar V, Sathish T, Sarma P. Nickel-impregnated silica nanoparticle synthesis and their evaluation for biocatalyst immobilization. Appl Biochem Biotechnol. 2010; 160(7): 1888-95. DOI: $10.1007 / \mathrm{s} 12010-009-8726-5$

67- Montes-Burgos I, Walczyk D, Hole P, Smith J, Lynch I, Dawson K. Characterisation of nanoparticle size and state prior to nanotoxicological studies. J Nanopart Res. 2010; 12(1): 47-53. DOI: 10.1007/s11051-009-9774-z 